Proc. Estonian Acad. Sci. Geol., 2003, 52, 1, 28-41

\title{
Current primary pedogenesis on Devonian sandstone in southern Estonia
}

\author{
Loit Reintam
}

Institute of Soil Science and Agrochemistry, Estonian Agricultural University, Viljandi Road, Eerika, 51014 Tartu, Estonia; loit@eau.ee

Received 19 April 2002

\begin{abstract}
A profile of Eutric Cambisol, formed during 50-55 years on the cross-bedded whitishgrey Devonian sandstone of the Burtnieki Stage, was studied on the excavated outcrop on the bank of the Helme River at Helme, southern Estonia. The topsoil of $10 \mathrm{~cm}$, being the A-Bw subsection, represents the result of humus accumulation, pedogenetic weathering of the sand fractions, and the accumulation in situ of silt and clay in the initial sand column of $6.18 \mathrm{~cm}$. Considerable loosening, accompanied with the upward expansion of the solum, has taken place at an annual rate of $0.7-$ $0.8 \mathrm{~mm}$. As a consequence of interfraction changes, $260-290 \mathrm{~g} \mathrm{~m}^{-2} \mathrm{yr}^{-1}$ of fine textural particles and $100-120 \mathrm{~g} \mathrm{~m}^{-2} \mathrm{yr}^{-1}$ of chemical constituents have accumulated in the thin solum, while some air deposition and surface lateral inflow cannot be excluded. The annual input of organic carbon at a rate of $25-28 \mathrm{~g} \mathrm{~m}^{-2}$ has operated as the driving force for rapid and intensive soil formation of accumulative origin. Fulvic acids have played a great role in the progress of initial pedogenesis, while the formed fulvates bound with alkaline earths favour the development of accumulative phenomena. Increase in base exchange capacity of the solum several times is the direct result of accumulation of humus, silt, and clay.
\end{abstract}

Key words: primary pedogenesis, Devonian sandstone, accumulative soil processes, Cambisol.

\section{INTRODUCTION}

Soil formation on outcropping rocks and deposits of any origin has always been in the focus of studies of primary ecosystem processes. The use of archaeological objects has made it possible to ascertain the rate of soil formation during centennia and/or millennia (Aleksandrovski 1983; Holliday 1985; Reintam 1994, 2001b; Reintam \& Lang 1999). Detritus and tailings of opencast quarries represent suitable objects for the study of initial soil formation during several years and/or decades (Schafer et al. 1980; Roberts et al. 1988a, 1988b; Fedorets et al. 1998; Reintam \& Kaar 1999; Tribis 2000; Reintam et al. 2001). Special experiments have also been performed and studied having this aim in view (Gagarina \& 
Tsyplenkov 1974; Graham et al. 1995; Reintam 1995, 1997; Tice et al. 1996; Beschow et al. 2000; Romanya et al. 2000). All these investigations demonstrate the relative rapidity of contemporary soil formation.

At the end of the 1990s we carried out recurrent studies in some areas of the International Biological Programme to establish contemporary pedogenetic changes in several soil types (Reintam 1999, 2000, 2001a). Modern argillization as well as rapid argilluviation were found to have occurred within two-three decades. Clear 33-year contemporary podzolization was evident in pure sand overgrown with green mosses and covered with the newly formed forest floor during this time (Reintam 2001a). Similar phenomena have developed under afforested dunes in San Francisco (Amundson \& Tremback 1989) and in the Falkland Islands (Wilson 2001). Thus primary pedogenesis in limestone bedrock and Quaternary deposits as well as contemporary genetic changes in particular soils have been a rather frequent object of research and discussion. However, as exposures of Devonian sandstones are rather rare, we had no data about initial soil formation in these materials. Still, some information has been available for corresponding buried palaeosols (Williams et al. 1996).

This study focuses on soil formation on light-coloured Middle Devonian sandstone in the bottom of a former opencast within about 50-55 years. The object was discovered occasionally on the route of a soil expedition to southern Estonia in 1998.

\section{MATERIAL AND METHODS}

Location, site, soil, and sampling

Devonian sandstone of the Burtnieki Stage (Kleesment \& Mark-Kurik 1997) crops out at Helme, southern Estonia $\left(58^{\circ} 01^{\prime} \mathrm{N}, 25^{\circ} 53^{\prime} \mathrm{E}\right)$ at the northern verge of the valley of the Helme River. Cross-bedded slightly cemented whitish-grey (10YR7/1) and slightly yellowish-grey (10YR7/6) Middle Devonian sandstone is traversed by reddish-brown stripes (5YR5/8) which are partly inclined and partly intersect the former (Fig. 1). According to oral information obtained from local citizens, sand was excavated here in the late 1930s. In 1939-42, the vegetation was absent and pure light-coloured sandstone was exposed. Although its excavation was already prohibited, digging still continued in places and two outcrops formed. One is located about some tens of metres north of the village road at the level of the inter-valley plateau, the other above the waterlogged bottom of the river valley, right beside the road (Fig. 2). The flat area between these outcrops is covered with herbs and grasses and some grey alder (Alnus incana) bushes. Two elderly local inhabitants suggested that the vegetation had formed not earlier than 55 years and not later than 45-50 years ago. As far as they could remember, the first traces of soil were evident about 50-55 years ago. Considering these suggestions, we used 50-55 years as time in our calculations, because it was impossible to find more exact documented data about the spontaneous appearance and development of both the vegetation and the soil. 


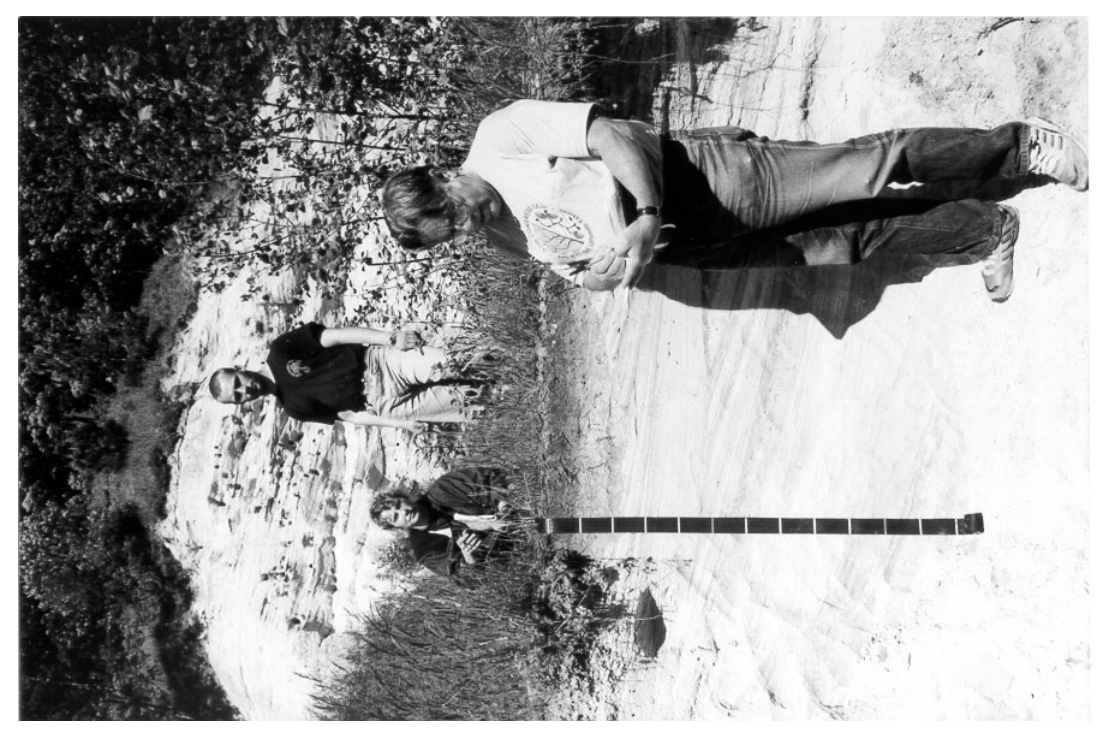

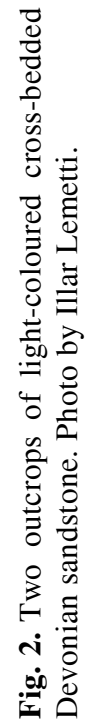

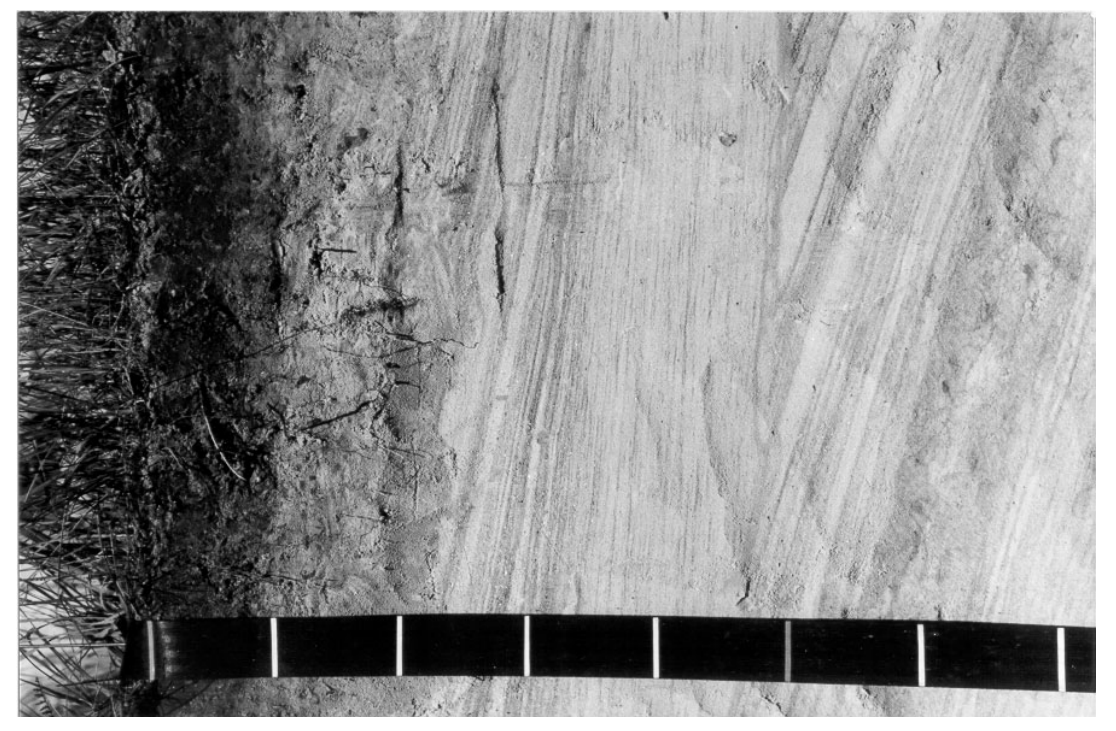

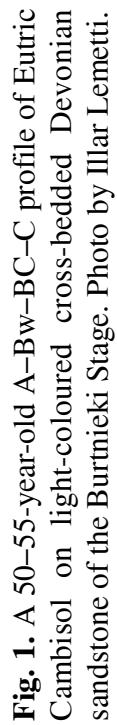


A soil section has formed in the thin top of the opencast (Fig. 1). As a result of humus accumulation, the depth of the A-horizon (10YR3/1) is $8 \mathrm{~cm}$; it is commonly rooted by fine and medium roots, and its boundary is gradually clear and smooth. The next, brown Bw-horizon (10YR5-6/4) with a slightly irregular boundary is silty, in situ enriched with humus and contains moderately few fine roots. Although the horizon is only $2-3 \mathrm{~cm}$ thick, it is clearly pedogenetic and can be qualified as cambic. The original cross-bedded lamination has disappeared and/or been disguised both in the A- and Bw-horizons during initial soil formation. The transitional BC-horizon (10YR7/3) is residually cross-bedded across the whole of its depth of $10-13 \mathrm{~cm}$. Some channels of fine and medium roots are greyish-brown (10YR5/4) owing to accumulated in situ humus substances inside them. Abundant sparkling grains of muscovite are present through the entire section, indicating that the soil has formed on Devonian material. Deeper than 20-23 cm occurs practically unchanged light-coloured Devonian bedrock. Sporadic occurrence of such light varieties is characteristic of the "Old Red" area, especially at lagoon sites where the formation of iron films on fine quartz grains was inhibited.

Well-known methods of soil science were applied in soil sampling by formed genetic horizons as well as in their morphological description (Schoeneberger et al. 1998). Each sample was compiled as an average of ten individual samples from different points of the respective horizon and/or initial Devonian sandstone. The bulk density of the soil horizons and initial sandstone was determined in four replications using a steel cylinder of $50 \mathrm{~cm}^{3}$. Accuracy requirements for sampling, laboratory techniques, and measurements were satisfied as for any reference profile (Batjes \& van Engelen 1997).

\begin{abstract}
Analyses
Laboratory analyses of the soil were performed at the Institute of Soil Science and Agrochemistry, Estonian Agricultural University. Fine earth with particle size $<1 \mathrm{~mm}$ was used. The grain-size fraction of 1-2 mm was absent. Samples for the determination of particle size were treated with sodium pyrophosphate to break down aggregates. Sands were sieved and fractions $<0.05 \mathrm{~mm}$ were determined by pipette analysis (Pipette Apparatus Table Model 7 Samples). Total chemical analysis was carried out after alkaline fusion treatment. Iron and aluminium were detected with sulphosalicylic acid and aluminone, respectively, alkaline earths, potassium, and sodium by flame photometry. Carbonates were determined acidometrically for the recalculation of the measurement data. The obtained results were expressed for ignited noncalcareous material (Arinushkina 1970; van Ranst et al. 1999). The reliability of these techniques was repeatedly verified by atomic absorption spectrometry.

The group and fractional composition of humus was determined by alternate acid-alkaline treatment using the Tyurin-Ponomareva volumetric method (Ponomareva 1957). The results were expressed in the percentages of organic carbon.
\end{abstract}


Group composition represents humic acids, fulvic acids, and humins (insoluble residue). Fractions within the groups are the following: 1a - free fulvic acids (only in the group of fulvic acids); 1 - humic and fulvic acids bound with mobile $\mathrm{R}_{2} \mathrm{O}_{3}\left(\mathrm{Al}_{2} \mathrm{O}_{3}\right.$ and $\left.\mathrm{Fe}_{2} \mathrm{O}_{3}\right) ; 2$ - humic and fulvic acids bound with alkaline earths $(\mathrm{Ca}, \mathrm{Mg}) ; 3$ - humic and fulvic acids bound with immobile $\mathrm{R}_{2} \mathrm{O}_{3}$ and clay material. The humic:fulvic ratio (HA:FA) represents the integral parameter of the maturity and mobility as well as humicity ( $>1$, according to some authors $>0.7)$ and/or fulvicity $(<0.7)$ of humus. The ratio of the 1 st to the 2 nd fraction characterizes the ratio of brown humic-fulvic complexes, bound with mobile sesquioxides, to grey (black) complexes bound with calcium and magnesium. Decalcification with $0.05 \mathrm{M}$ sulphuric acid forms part of humus fractioning, which enables the determination of the second and the third fraction as well as the hydrolysate of $0.5 \mathrm{M}$ sulphuric acid (Ponomareva 1957). Decalcinate contains metals released from humates and fulvates (salts of both humus acids).

Total amounts of organic carbon and nitrogen were ascertained by the Tyurin and Kjeldahl methods, respectively. It is necessary to point out that the Anne method known in the Western countries (van Ranst et al. 1999) is equivalent to the Tyurin method used in this study. Tithionite-extractable (total nonsiliceous) iron $\left(\mathrm{Fe}_{\mathrm{d}}\right)$, oxalate-extractable amorphous iron, aluminium, and silica $\left(\mathrm{Fe}_{\mathrm{o}}, \mathrm{Al}_{\mathrm{o}}, \mathrm{Si}_{\mathrm{o}}\right)$ were measured after Coffin and Tamm, respectively; iron activity was calculated after Schwertmann (van Ranst et al. 1999). Base exchange capacity (BEC) and exchangeable bases were measured by the percolation of the samples with ammonium acetate at $\mathrm{pH} 7.0$ and were expressed in $\mathrm{cmol} \mathrm{kg}^{-1}$. The $\mathrm{pH}$ of both water and $1 \mathrm{M} \mathrm{KCl}$ suspensions was measured potentiometrically with the pH-meter Jenway 3071. Exchange acidity $\left(\mathrm{H}^{+}+\mathrm{Al}^{3+}\right)$ was ascertained after Daikuhara-Sokolov in $1 \mathrm{M} \mathrm{KCl}$ (Kitse \& Rooma 1984).

The quantitative origin of current changes was established by the material balance method (Targulian et al. 1974; Rozanov 1975; Reintam 1985, 1997; van Breemen \& Buurman 1998). The weight of the soil horizons and their textural and chemical constituents as of 1998 were compared with those recorded for initial Devonian sandstone at depths of 30-40 cm. According to Targulian et al. (1974) and Rozanov (1975), the sand fractions $>0.05 \mathrm{~mm}$ were regarded as an indicator of the initial status prior to pedogenesis. Changes in the thickness (depth) of the initial column of the soil horizons with an area of one square metre were calculated from the measurement data using formulas published elsewhere (Targulian et al. 1974; Rozanov 1975; Reintam 1997).

\section{RESULTS AND DISCUSSION}

Synchronously with the progress of the vegetative cover, organic matter accumulated in the thin top of initial sandstone. The total amount of organic carbon in the humus horizon (epipedon) with a thickness of $8 \mathrm{~cm}$ is about $1.4 \mathrm{~kg} \mathrm{~m}^{-2}$ (Table 1). Average annual increment is $25-28 \mathrm{~g} \mathrm{~m}^{-2}$ of organic carbon 
and 2.6-2.9 $\mathrm{g} \mathrm{m}^{-2}$ of nitrogen against the background of a thickness increase of $1.4-1.6 \mathrm{~mm} \mathrm{yr}^{-1}$. The low $\mathrm{C}: \mathrm{N}$ ratio indicates the presence of nitrogen bridges in polyphenolic molecules and a rather high maturity of humus. Except for thickness, all parameters of epipedon humus satisfy the criteria of mollic (Driessen et al. 2001). According to Romanya et al. (2000), afforestation of Mediterranean Eutric Cambisol on granodiorite resulted in about $10 \mathrm{~g} \mathrm{~m}^{-2} \mathrm{yr}^{-1}$ increase in organic carbon in the topmost $5 \mathrm{~cm}$, while in the ectoorganic layers the respective increase was similar to that observed in our object.

The situation is almost similar in the very thin but clearly developed cambic Bw-horizon. Although the contents of organic carbon and nitrogen in it are much smaller than even per $\mathrm{cm}$ of the epipedon, both organic constituents are

Table 1. Humus composition in the percentages of organic carbon

\begin{tabular}{|c|c|c|}
\hline Characteristic & A-horizon & Bw-horizon \\
\hline Thickness, cm & 8 & 2 \\
\hline Bulk density, $\mathrm{Mg} \mathrm{m}^{-3} *$ & 1.06 & 1.55 \\
\hline Colour & 10YR3/1 & 10YR5-6/4 \\
\hline Weight of horizon, $\mathrm{kg} \mathrm{m}^{-2}$ & 84.8 & 31.0 \\
\hline Content of organic carbon, $\mathrm{g} \mathrm{kg}^{-1}$ & 16.6 & 4.5 \\
\hline Pool of organic carbon, $\mathrm{g} \mathrm{m}^{-2}$ & 1407.7 & 139.5 \\
\hline Content of total nitrogen, $\mathrm{g} \mathrm{kg}^{-1}$ & 1.7 & 0.8 \\
\hline Pool of total nitrogen, $\mathrm{g} \mathrm{m}^{-2}$ & 144.2 & 24.8 \\
\hline $\mathrm{C}: \mathrm{N}$ & 9.8 & 5.6 \\
\hline Humic acids (HA) 1 & 1.8 & 2.2 \\
\hline 2 & 6.6 & 11.1 \\
\hline 3 & 2.4 & 2.3 \\
\hline Total & 10.8 & 15.6 \\
\hline Fulvic acids (FA) 1a & 2.4 & 8.9 \\
\hline 1 & 16.3 & 6.7 \\
\hline 2 & 31.9 & 28.9 \\
\hline 3 & 7.8 & 8.9 \\
\hline Total & 58.4 & 53.4 \\
\hline Hydrolysate of $0.5 \mathrm{M} \mathrm{H}_{2} \mathrm{SO}_{4}$ & 9.6 & 11.1 \\
\hline Total soluble & 78.8 & 80.1 \\
\hline Insoluble & 21.2 & 19.9 \\
\hline Humic acids : fulvic acids & 0.2 & 0.3 \\
\hline First fraction : second fraction & 0.5 & 0.2 \\
\hline Decalcinate, $\mathrm{g} \mathrm{kg}^{-1} \mathrm{Fe}$ & 0.4 & 0.4 \\
\hline $\mathrm{Ca}$ & 6.6 & 2.4 \\
\hline $\mathrm{Mg}$ & 6.0 & 2.6 \\
\hline
\end{tabular}

* The bulk density of the BC-horizon and Devonian sand (C-horizon) is $1.64 \mathrm{Mg} \mathrm{m}^{-3}$. 
of in situ origin. Undoubtedly, such a weathered horizon, enriched with humus, represents the first product of primary pedogenesis. Against the background of the progressing accumulation of humus the development of the ochric epipedon takes place on the basis of the Bw-horizon. Gradual development of both humus accumulation and weathering appears to favour the penetration of both horizons into depth.

Humus is clearly fulvic in both horizons (Table 1), while Ca-fulvates are prevalent. As in any outcome of primary pedogenesis (Reintam 1995), a large proportion of humus can be attributed to fulvic acids bound with stable sesquioxides and secondary minerals (3rd fraction) as well as occurring in the interlayeral structure of the latter (hydrolysate). The content of free fulvic acids (fraction 1a) shows considerable increase in the Bw-horizon, favouring there, through organicmineral interactions in situ, an intensive devolopment of cambic properties in depth. The amount of humic acids is significantly smaller, while about 60-70\% of them are bound with alkaline earths (Table 1). However, the amount of humic acids is still sufficient to ensure the stability of humus, the loosening of the mineral stratum, and the progress of the initial epipedon. Aluminium is not yet mobilized, and humic-fulvic complexes of the first fraction are bound only with iron.

The $\mathrm{pH}$ is uniformly neutral across the entire profile (Table 2). The low exchange acidity of Devonian sandstone has completely disappeared from the formed solum. This can be explained by the intensive formation of the colloidal complex and by the rapid progress of BEC which is more than ten times higher in the A- and Bw-horizons than in initial sandstone at a depth of $30-40 \mathrm{~cm}$. Exchangeable calcium accounts for $88-89 \%$ of total BEC in the soil horizons and $85-87 \%$ in parent material. Average annual increase in BEC is $0.15-0.16$ and $0.10-0.11 \mathrm{cmol} \mathrm{kg}^{-1}$ for the A- and Bw-horizons, respectively. Accumulativity of exchangeable bases within only some decades of primary pedogenesis is characteristic of any initial soil (Beschow et al. 2000), among them even sandy minipodzol under a forest vegetation (Reintam 2001a). Exchange absorption of bases which are bound biologically and released in the process of the transformation of organic residues is more intensive under grasses in the conditions of comparatively high $\mathrm{pH}$ values and alternating moistening and drying-up typical of sands.

Table 2. Exchange properties, $\mathrm{cmol} \mathrm{kg}^{-1}$

\begin{tabular}{l|c|c|c|c|c|c|c|c}
\hline $\begin{array}{c}\text { Horizon and depth, } \\
\text { cm }\end{array}$ & $\mathrm{Ca}^{2+}$ & $\mathrm{Mg}^{2+}$ & $\mathrm{K}^{+}$ & $\mathrm{Na}^{+}$ & $\mathrm{BEC}$ & $\mathrm{H}_{5.6^{*}}$ & $\mathrm{pH}_{\mathrm{H}_{2} \mathrm{O}}$ & $\mathrm{pH}_{\mathrm{KCl}}$ \\
\hline A 0-8 & 7.62 & 0.84 & 0.14 & 0.05 & 8.65 & 0 & 7.1 & 7.1 \\
Bw 8-10 & 5.09 & 0.54 & 0.12 & 0.02 & 5.77 & 0 & 7.1 & 7.1 \\
BC 10-20 & 1.51 & 0.12 & 0.06 & 0.01 & 1.70 & 0 & 7.2 & 6.9 \\
C 20-30 & 1.09 & 0.11 & 0.06 & 0.01 & 1.27 & 0.31 & 7.2 & 6.5 \\
C 30-40 & 0.47 & 0.03 & 0.03 & 0.01 & 0.54 & 0.10 & 7.3 & 6.8 \\
* Exchange acidity. & & & & & & & &
\end{tabular}


Like decalcinate, amorphous aluminium is practically lacking in the oxalate extraction (Table 3). Its mobilization appears to be inhibited in the conditions of neutral reaction and complete base saturation. Only some traces of it were found in the oxalate extraction. The accumulation of amorphous iron is also rather slow. About two-thirds of it are subjected to rapid crystallization while in the BC-horizon this process is many times more intensive. Possibly there occurs hydrothermal gradient for inhibition of the persistence of amorphous compounds. According to Wang et al. (1989), appreciable amounts of crystalline iron oxide may slow down any eluvial process in the soil. The same applies also to silica.

Changes in the granulometric composition are typical of weathering in situ under the impact of organic substances and hydrothermal agents. Although sand fractions are of slightly different distribution in cross-bedded Devonian layers, their sum is rather similar (Table 4). Clay is lacking; only brown-coloured internal stripes and lines contain some clay. During the initial soil formation of 50-55 years, silt and clay have accumulated as a consequence of the disintegration of fine sand, while coarse and medium sands appear to have been residual in crossbedded structure where current soil formation took place. The distribution of sand and silt + clay is completely balanced deeper than $10 \mathrm{~cm}$. This phenomenon indicates that soil processes have affected the exchangeable complex and

Table 3. The content and pool of nonsiliceous substances

\begin{tabular}{|c|c|c|c|c|c|c|c|c|}
\hline \multirow{2}{*}{$\begin{array}{l}\text { Horizon and depth, } \\
\mathrm{cm}\end{array}$} & \multicolumn{4}{|c|}{ Content, $\mathrm{g} \mathrm{kg}^{-1}$} & \multirow{2}{*}{$\mathrm{Fe}_{\mathrm{o}} / \mathrm{Fe}_{\mathrm{d}}$} & \multicolumn{3}{|c|}{ Pool, $\mathrm{g} \mathrm{hor}^{-1} \mathrm{~m}^{-2}$} \\
\hline & $\mathrm{Fe}_{\mathrm{d}}$ & $\mathrm{Fe}_{\mathrm{o}}$ & $\mathrm{Al}_{\mathrm{O}}$ & $\mathrm{Si}_{\mathrm{o}}$ & & $\mathrm{Fe}_{\mathrm{d}}$ & $\mathrm{Fe}_{\mathrm{o}}$ & $\mathrm{Si}_{\mathrm{o}}$ \\
\hline A $0-8$ & 3.6 & 1.3 & traces & 0.6 & 36 & 305 & 110 & 51 \\
\hline Bw 8-10 & 2.7 & 1.0 & traces & 0.2 & 37 & 84 & 31 & 6 \\
\hline BC 10-20 & 4.3 & 0.4 & traces & 0.0 & 9 & 705 & 66 & 6 \\
\hline C $20-30$ & 1.0 & 0.4 & traces & 0.1 & 40 & 164 & 66 & 16 \\
\hline C $30-40$ & 1.6 & 0.3 & traces & 0.1 & 19 & 262 & 49 & 16 \\
\hline
\end{tabular}

Table 4. Grain-size fractions (in $\mathrm{mm}$ ) and their pool

\begin{tabular}{l|r|r|r|r|r|r|r|r}
\hline $\begin{array}{c}\text { Horizon and } \\
\text { depth, cm }\end{array}$ & \multicolumn{5}{|c|}{ Content, $\mathrm{g} \mathrm{kg}^{-1}$} & \multicolumn{3}{c}{ Pool, $\mathrm{g} \mathrm{m}^{-2}$ hor $^{-1}$} \\
\cline { 2 - 9 } & $1-0.5$ & $0.5-0.25$ & $0.25-0.05$ & $0.05-0.002$ & $<0.002$ & Sand & \multicolumn{1}{c}{ Silt } & Clay \\
\hline A 0-8 & 34 & 200 & 618 & 146 & 2 & 72250 & 12381 & 170 \\
Bw 8-10 & 20 & 205 & 554 & 166 & 55 & 24149 & 5146 & 1705 \\
BC 10-20 & 6 & 114 & 801 & 77 & 2 & 151044 & 12628 & 328 \\
C 20-30 & 6 & 127 & 805 & 62 & 0 & 153832 & 10168 & 0 \\
C 30-40 & 1 & 22 & 928 & 49 & 0 & 155964 & 8036 & 0 \\
Brown line & 1 & 19 & 916 & 32 & 32 & \multicolumn{3}{c}{ Impossible to detect } \\
Grey stripe & 2 & 66 & 874 & 58 & 0 & because of small thickness \\
C 50-60 & 4 & 53 & 883 & 60 & 0 & 154160 & 9840 & 0
\end{tabular}


nonsiliceous substances but have not had any impact either on bulk density (uniformly $1.64 \mathrm{Mg} \mathrm{m}^{-3}$ in the BC-horizon and in the upper layers of initial Devonian sandstone) or on the translocation of the fractions. Only a balanced accumulation of silt and clay at the expense of disintegrated sand has taken place in the BC-horizon (Table 4).

Pedogenetic changes in granulometric fractions are obvious in the two upper horizons. In spite of the contemporary accumulation of silt and clay, considerable decrease in the content of sand fractions has resulted in the $31 \%$ loss of the weight of initial sandstone (Tables 4 and 5), which makes 87-96 $\mathrm{g} \mathrm{m}^{-2} \mathrm{yr}^{-1} \mathrm{~cm}^{-1}$ of the solum. In fact, judging by changes in bulk density and by the accumulation of organic matter (Table 1), a loosening and an upward expansion of the solum have taken place. According to mineral indicators (Targulian et al. 1974; Rozanov 1975; Reintam 1997, 1999), these horizons have been formed on initial sandstone which was $3.82 \mathrm{~cm}$ thinner $50-55$ years ago than the current solum (Table 5). The average annual rate of upward expansion has been extremely high $(69-76 \mu \mathrm{m})$, probably not only due to the common root system and accumulated humus but also because of the activity of fauna, as suggested by Kristiansen \& Amelung (2001) in their study on the effect of the activity of ants on soil status.

After recalculations of the depths of sand for the A- and Bw-horizons (4.63 and $1.55 \mathrm{~cm}$, respectively), the solum proved accumulative at the expense of silt in the A-horizon and silt and clay in the Bw-horizon altogether by $14 \%$ of initial sandstone (Table 5). The average annual increase in soil mass is $263-289 \mathrm{~g} \mathrm{~m}^{-2}$, of which 161-177 $\mathrm{g} \mathrm{m}^{-2}$ can be ascribed to the A-horizon. Partial input of silt by air deposition and/or surface flow cannot be excluded here. However, 38-39\% of annual increase in the content of silt and clay can be attributed to the cambic $\mathrm{Bw}$-horizon where only some lateral removal of clay could have taken place. Although orientated clayskins are still lacking, it is possible that the Bw-horizon has been formed at the initial site of the brown stripe originally enriched with clay.

Table 5. Changes in the pool of grain-size fractions

\begin{tabular}{|c|c|c|c|c|c|c|c|c|c|c|}
\hline \multirow{2}{*}{$\begin{array}{c}\text { Horizon } \\
\text { and } \\
\text { thick- } \\
\text { ness, cm }\end{array}$} & \multicolumn{4}{|c|}{ Pool of natural soil, $\pm \mathrm{g} \mathrm{m}^{-2}$} & \multirow{2}{*}{$\begin{array}{c}\mathrm{CTS}, \\
\mathrm{cm}\end{array}$} & \multirow{2}{*}{$\begin{array}{l}\text { CPS, } \\
\mathrm{g} \mathrm{m}^{-2}\end{array}$} & \multicolumn{4}{|c|}{ Corrected pool, $\pm \mathrm{g} \mathrm{m}^{-2}$} \\
\hline & Sand & Silt & Clay & Total & & & Sand & Silt & Clay & Total \\
\hline A 8 & -52521 & +5952 & +170 & -46399 & 4.63 & 75932 & +39 & +8660 & +170 & +8869 \\
\hline Bw 2 & -7044 & +3539 & +1705 & -1800 & 1.55 & 25420 & -26 & +3901 & +1705 & +5580 \\
\hline BC 10 & -4920 & +4592 & +328 & 0 & & No & hange & or corre & ions & \\
\hline Total & -64485 & +14083 & +2203 & -48199 & 6.18 & 101352 & +13 & 12561 & 1875 & +14449 \\
\hline
\end{tabular}

CTS - corrected thickness of initial sand; CPS - corrected pool of initial sand.

For the pools of the fractions see Table 4. 
Owing to the different distribution of seams with iron films, alumosilicates, and micas, the chemical composition of cross-bedded Devonian sandstone is rather variable regarding iron, aluminium, magnesium, and potassium (Table 6). Chemical poverty tends to increase with depth. Nevertheless, differences in the sum of the elements between the horizons do not exceed 3-4\% (Table 7). The high chemical variability noted in tailings of opencast quarries by Fedorets et al.

Table 6. Chemical composition and pools of the elements

\begin{tabular}{|c|c|c|c|c|c|c|c|c|c|c|}
\hline \multirow{2}{*}{$\begin{array}{l}\text { Ele- } \\
\text { ment }\end{array}$} & \multicolumn{5}{|c|}{ Content in horizons, $\mathrm{g} \mathrm{kg}^{-1}$} & \multicolumn{5}{|c|}{ Pool in horizons, $\mathrm{g} \mathrm{m}^{-2}$ hor $^{-1}$} \\
\hline & $\begin{array}{c}\mathrm{A} \\
0-8 \\
\end{array}$ & $\begin{array}{c}\mathrm{Bw} \\
8-10 \\
\end{array}$ & $\begin{array}{c}\mathrm{BC} \\
10-20\end{array}$ & $\begin{array}{c}\mathrm{C} \\
20-30 \\
\end{array}$ & \begin{tabular}{|c|}
$\mathrm{C}$ \\
$30-40$ \\
\end{tabular} & $\begin{array}{c}\text { A } \\
0-8\end{array}$ & $\begin{array}{c}\mathrm{Bw} \\
8-10 \\
\end{array}$ & $\begin{array}{c}\mathrm{BC} \\
10-20 \\
\end{array}$ & $\begin{array}{c}\mathrm{C} \\
20-30 \\
\end{array}$ & $\begin{array}{c}\text { C } \\
30-40 \\
\end{array}$ \\
\hline $\mathrm{Si}$ & 14.8 & 413.6 & 422.7 & 403.6 & 438.7 & 35175 & 12822 & 69323 & 66190 & 71947 \\
\hline $\mathrm{Fe}$ & 7.5 & 7.1 & 5.4 & 10.3 & 3.3 & 636 & 220 & 886 & 1689 & 541 \\
\hline $\mathrm{Al}$ & 27.1 & 33.2 & 31.8 & 47.3 & 18.5 & 2298 & 1029 & 5215 & 7757 & 3034 \\
\hline $\mathrm{P}$ & 5.8 & 3.0 & 1.1 & 1.5 & 0.7 & 492 & 93 & 180 & 246 & 115 \\
\hline $\mathrm{Ca}$ & 1.6 & 4.1 & 6.1 & 8.9 & 8.6 & 136 & 12 & 1000 & 1460 & 1410 \\
\hline $\mathrm{Mg}$ & 7.2 & 3.5 & 2.0 & 4.0 & 1.6 & 611 & 108 & 328 & 656 & 262 \\
\hline K & 14.2 & 15.1 & 13.6 & 22.2 & 10.7 & 1204 & 468 & 2230 & 3641 & 1755 \\
\hline $\mathrm{Na}$ & 1.8 & 1.3 & 0.9 & 1.3 & 1.3 & 153 & 40 & 148 & 213 & 213 \\
\hline Total & 480.0 & 480.9 & 483.6 & 499.1 & 483.4 & 40705 & 14907 & 79310 & 81852 & 79277 \\
\hline
\end{tabular}

Table 7. Changes in the pool of chemical elements during 50-55 years in comparison with the corrected thickness of initial Devonian sand, $\pm \mathrm{g} \mathrm{m}^{-2}$ hor $^{-1}$

\begin{tabular}{|c|c|c|c|c|c|c|c|}
\hline $\begin{array}{l}\text { Ele- } \\
\text { ment }\end{array}$ & $\begin{array}{l}A+B w \\
10 \mathrm{~cm} \\
\end{array}$ & $\begin{array}{c}C^{*} \\
6.18 \mathrm{~cm} \\
\end{array}$ & $\begin{array}{l}\text { Difference } \\
\pm \mathrm{g} \mathrm{m}^{-2} \text { hor }^{-1}\end{array}$ & $\begin{array}{c}C^{* *} \\
6.18 \mathrm{~cm} \\
\end{array}$ & $\begin{array}{c}\text { Difference } \\
\pm \mathrm{g} \mathrm{m}^{-2} \text { hor }^{-1}\end{array}$ & $\begin{array}{l}\mathrm{C} \text { for } \mathrm{BC} \\
10 \mathrm{~cm}^{* *}\end{array}$ & $\begin{array}{l}\text { Difference } \\
\pm \mathrm{g} \mathrm{m}^{-2} \text { hor }^{-1}\end{array}$ \\
\hline $\mathrm{Si}$ & 47997 & 44463 & +3534 & 42689 & +5308 & 69069 & +254 \\
\hline $\mathrm{Fe}$ & 856 & 334 & +522 & 689 & +167 & 1115 & -229 \\
\hline $\mathrm{Al}$ & 3327 & 1875 & +1452 & 3943 & -616 & 5395 & -180 \\
\hline $\mathrm{P}$ & 585 & 71 & +514 & 112 & +473 & 180 & 0 \\
\hline $\mathrm{Ca}$ & 263 & 872 & -609 & 892 & -629 & 1435 & -435 \\
\hline $\mathrm{Mg}$ & 719 & 162 & +557 & 294 & +425 & 459 & -131 \\
\hline K & 1672 & 1084 & +588 & 1672 & 0 & 2698 & -468 \\
\hline $\mathrm{Na}$ & 193 & 132 & +61 & 132 & +61 & 213 & -65 \\
\hline Total & 55612 & 48993 & +6619 & 50423 & +5 189 & 80564 & -1254 \\
\hline Annual & & & $+120-132$ & & +94-104 & & $-22-25$ \\
\hline
\end{tabular}

* The characteristics of initial sand were calculated on the basis of the data from a depth of $30-40 \mathrm{~cm}$, presented in Table 6.

** The characteristics of initial sand were calculated on the basis of the average data from the depths of $20-30$ and $30-40 \mathrm{~cm}$, presented in Table 6 . These data were also used for the comparison of the BC-horizon. 
(1998) is lacking in primary pedogenesis on Devonian sandstone. Obviously, soil formation favours accumulation of iron, aluminium, phosphorus, and magnesium but loss of calcium. However, initial stratification can play some role in this case. Against the background of balance in the textural constituents of the BC-horizon (Tables 4 and 5), a slight removal of elements $\left(2.2-2.5 \mathrm{~g} \mathrm{~m}^{-2} \mathrm{yr}^{-1} \mathrm{~cm}^{-1}\right.$ ) has taken place there (Tables 6 and 7). Since the annual losses of merely calcium and potassium amounted to $8-9 \mathrm{~g} \mathrm{~m}^{-2}$ per $10 \mathrm{~cm}$, being about two to three times lower for the other elements, general chemical relationships can be interpreted either as slightly changed or practically unchanged in the BC-horizon. This is not valid for the sum of the A- and Bw-horizons within the upper $10 \mathrm{~cm}$.

After making corrections with respect to the mineral indicators (Tables 4 and 5), it was found that soil formation began 50-55 years ago on top of Devonian sandstone. The thickness of the upper part of the sandstone was only $6.18 \mathrm{~cm}$ versus contemporary $10 \mathrm{~cm}$ for the two above mentioned horizons. The initial data for the corrected weights of the elements in Devonian sandstone with a thickness of $6.18 \mathrm{~cm}$ were taken from Table 6 and are presented, together with the differences between the soil $(\mathrm{A}+\mathrm{Bw}=10)$ and parent sand $\left(\mathrm{C}^{*}\right.$ and $\left.\mathrm{C}^{* *}\right)$, in Table 7. The total range of profile accumulativity (6-8\% of the initial amount) appears to be about twice as low as for textural constituents. This situation can be explained by the existence of chemical constituents in the form of oxides and silicates, containing oxygen, but not in the form of pure elements. As mentioned above, surface and air deposition of silty material can accumulate after the breakdown and removal of calcareous components without respective changes in its chemical status. The appreciable accumulation of phosphorus appears to be of anthropogenic origin and is associated with deposition of silt from the surrounding fields. On the other hand, the average annual gain of about $100-120 \mathrm{~g} \mathrm{~m}^{-2}$ per solum with a thickness of $10 \mathrm{~cm}$ seems to be insignificant and much closer to the desired analytical accuracy.

\section{CONCLUSIONS}

Contemporary initial soil formation on light-coloured Devonian sandstone was first detected in Estonia. A well-diagnosable A-Bw-BC profile with a total depth of $20 \mathrm{~cm}$ has developed during 50-55 years. As a consequence of the humus accumulation, weathering in situ, and loosening of the initial sand column of $6.18 \mathrm{~cm}$, upward expansion progressed at a rate of $0.7-0.8 \mathrm{~mm} \mathrm{yr}^{-1}$, forming the $\mathrm{A}-\mathrm{Bw}$ subsection. The formed epipedon is still ochric but already rather close to mollic. The cambic horizon is thin but clearly expressed. Its presence allows qualification of this pedogenetic outcome as Eutric Cambisol. Ca-fulvic humus has been the driving force for the primary pedogenesis of accumulative origin. The thin A-Bw subsection is enriched with silt and clay as well as with the main chemical constituents. A considerable increase in base exchange capacity and in the crystalline form of nonsiliceous iron is characteristic of initial soil formation on Devonian sandstone. 


\section{ACKNOWLEDGEMENTS}

This study was financed by the Estonian Science Foundation (grant No. 2669). The final conclusion was made with the support of grant No. 4090. Special thanks belong to Mrs. Raja Kährik for performing the laboratory analyses and to Mrs. Ester Jaigma for the linguistic revision of the manuscript. I would like to thank Illar Lemetti, M.Sc., for making the photos and for collaboration in field work. The valuable comments and recommendations of anonymous referees are greatly appreciated.

\section{REFERENCES}

Aleksandrovski, A. I. 1983. Évolyutsiya pochv Vostochno-Evropeiskoj ravniny v golotsene. Nauka, Moscow (in Russian).

Amundson, R. G. \& Tremback, B. 1989. Soil development on stabilized dunes in Golden Gate Park, San Francisco. Soil Sci. Soc. Am. J., 53, 1798-1806.

Arinushkina, E. V. 1970. Rukovodstvo dlya khimicheskogo analiza pochv. Moscow University Press (in Russian).

Batjes, N. H. \& van Engelen, V. W. P. 1997. Guidelines for the Compilation of a 1:2500 000 SOTER Database (SOVEUR Project). Report 97/06, International Soil Reference and Information Centre, Wageningen.

Beschow, H., Gransee, A. \& Merbach, W. 2000. Soil development on loess substrate in central Germany - results of a long-term trial on soil formation. J. Plant Nutrition Soil Sci., 163, 359-366.

Driessen, P., Deckers, J., Spaargaren, O. \& Nachtergaele, F. (eds.). 2001. Lecture Notes on the Major Soils of the World. World Soil Resources Reports, 94. Food and Agriculture Organization of the United Nations, Rome.

Fedorets, N. G., Shil'tsova, G. V., Germanova, N. I., Antipina, G. S., Kryshen', A. M. \& Sokolov, A. I. 1998. Initial stages of soil formation on the tailings of an iron-ore deposit in the subzone of northern taiga in Karelia. Pochvovedenie (Eurasian Soil Sci.), 2, 133-139.

Gagarina, E. I. \& Tsyplenkov, V. P. 1974. Use of micromorphological method in modelling the modern process of soil formation. Pochvovedenie (Soviet Soil Sci.), 4, 20-27.

Graham, R. C., Ervin, J. O. \& Wood, H. B. 1995. Aggregate stability under oak and pine after four decades of soil development. Soil Sci. Soc. Am. J., 59, 1740-1744.

Holliday, V. T. 1985. Morphology of Late Holocene soils at the Lubbock Lake Archaeological Site, Texas. Soil Sci. Soc. Am. J., 49, 938-946.

Kitse, E. \& Rooma, I. 1984. Mullateaduse laboratoorne praktikum. Eesti Põllumajanduse Akadeemia, Tartu.

Kleesment, A. \& Mark-Kurik, E. 1997. Middle Devonian. In Geology and Mineral Resources of Estonia (Raukas, A. \& Teedumäe, A., eds.), pp. 112-121. Estonian Academy Publishers, Tallinn.

Kristiansen, S. M. \& Amelung, W. 2001. Abandoned anthills of Formica polyctena and soil heterogeneity in a temperate deciduous forest: morphology and organic matter composition. European J. Soil Sci., 52, 355-363.

Ponomareva, V. V. 1957. To the method for the study of soil humus after I. V. Tyurin's scheme. Pochvovedenie (Soviet Soil Sci.), 8, 66-71.

Reintam, L. 1985. Genetic characteristics of soils on red-brown moraine compared by the substance balance method. Soviet Soil Sci., 17, 13-22.

Reintam, L. 1994. Experience in the use of archaeological objects for the study of pedogenesis. In Transactions of the 15th World Congress of Soil Science. 6a, pp. 330-347. AcapulcoMexico. 
Reintam, L. 1995. Temporal and spatial changes in organic agents in the progress of primary pedogenesis during thirty years. Proc. Estonian Acad. Sci. Ecol., 5, 61-76.

Reintam, L. 1997. Pedogenetic changes in the quantity and distribution of textural and chemical soil constituents during thirty years. Proc. Estonian Acad. Sci. Biol. Ecol., 46, 174-190.

Reintam, L. 1999. Holocene and current changes in forest Stagnic Luvisol. Proc. Estonian Acad. Sci. Geol., 48, 228-250.

Reintam, L. 2000. Changes in forest rendzinas and Cambisols during three decades. Polish J. Soil Sci., XXXIII, 2, 81-89.

Reintam, L. 2001a. Current changes in forest Carbic Podzol and primary podzolization of sand. Baltic Forestry, 7, 1, 10-18.

Reintam, L. 2001b. Use of prehistoric human constructions for the study of pedogenesis. In Proceedings of the 1st International Conference on Soils and Archaeology (Füleky, G., ed.), pp. 116-119. Környezetkimelö Agrokemiaert Alapitvany, Gödöllö.

Reintam, L. \& Kaar, E. 1999. Development of soils on calcareous quarry detritus of open-pit oilshale mining during three decades. Proc. Estonian Acad. Sci. Biol. Ecol., 48, 251-266.

Reintam, L. \& Lang, V. 1999. The progress of pedogenesis within areas of prehistoric agriculture. Journal of the European Network of Scientific and Technical Cooperation for the Cultural Heritage. PACT, 57, 415-431.

Reintam, L., Kaar, E. \& Rooma, I. 2001. Development of forest-soil systems on quarry detritus of open-cast oil-shale mining. In Ecosystems and Sustainable Development III. Advances in Ecol. Sci., 10, 645-656.

Roberts, J. A., Daniels, W. L., Bell, J. C. \& Burger, J. A. 1988a. Early stages of mine soil genesis in a Southwest Virginia spoil lithosequence. Soil Sci. Soc. Am. J., 52, 716-723.

Roberts, J. A., Daniels, W. L., Bell, J. C. \& Burger, J. A. 1988b. Early stages of mine soil genesis as affected by topsoiling and organic amendments. Soil Sci. Soc. Am. J., 52, 730-738.

Romanya, J., Cortina, J., Palloon, P., Coleman, K. \& Smith, P. 2000. Modelling changes in soil organic matter after planting fast-growing Pinus radiata on Mediterranean agricultural soils. European J. Soil Sci., 51, 627-641.

Rozanov, B. G. 1975. Genetic Morphology of Soils. University Press, Moscow (in Russian).

Schafer, W. M., Nielsen, G. A. \& Nettleton, W. D. 1980. Minesoil genesis and morphology in a spoil chronosequence in Montana. Soil Sci. Soc. Am. J., 44, 802-807.

Schoeneberger, P. J., Wysocki, D. A., Benham, E. C. \& Broderson, W. D. (Revisers, Refiners, Compilers). 1998. Field Book for Describing and Sampling Soils. Version 1.1. National Survey Center, Natural Resources Conservation Service, U.S. Department of Agriculture, Lincoln, Nebraska.

Targulian, V. O., Sokolova, T. A., Birina, A. G., Kulikov, A. V. \& Tselishcheva, L. K. 1974. Arrangement, Composition and Genesis of Sod-Pale-Podzolic Soil Derived from Mantle Loams. Analytical Investigation. Xth Internat. Congress of Soil Science. Moscow.

Tice, K. R., Graham, R. C. \& Wood, H. B. 1996. Transformations of 2:1 phyllosilicates in 41-yearold soils under oak and pine. Geoderma, 70, 49-62.

Tribis, V. P. 2000. Soil formation in a remediated landfill site. Pochvovedenie (Eurasian Soil Sci.), 7, 898-904.

van Breemen, N. \& Buurman, P. 1998. Soil Formation. Kluwer Academic Publishers, Dordrecht.

van Ranst, E., Verloo, M., Demeyer, A. \& Pauwels, J. M. 1999. Manual for the Soil Chemistry and Fertility Laboratory. Analytical Methods for Soils and Plants, Equipment and Management of Consumables. University of Ghent, Gent, Belgium.

Wang, C., Ross, G. J. \& Protz, R. 1989. Effect of crystalline iron oxides on development and classification of podzolic soils in Western Labrador, Newfoundland. Soil Sci. Soc. Am. J., $\mathbf{5 3}, 870-875$.

Williams, C. A., Hills, L. V. \& Krause, F. F. 1996. Preserved organic matter and miospores in buried Middle Devonian (Givetian) paleosols: indicators of weathering, oxidation and maturity. Catena, 28, 1-19.

Wilson, P. 2001. Rate and nature of podzolisation in aeolian sands in the Falkland Islands, South Atlantic. Geoderma, 101, 77-86. 


\title{
Nüüdisaegne primaarne mullateke Devoni liivakivil Lõuna-Eestis
}

\begin{abstract}
Loit Reintam
Esmakordselt Eestis uuriti primaarset mullateket Devoni liivakivil Helmes Helme jõe vasemkaldal liivakivi kaevandamisest tekkinud terrassikujulisel avamusel. Küllastunud liivmulla (Eutric Cambisol) A-Bw-BC-profiil oli kujunenud 50-55 aasta jooksul Kesk-Devoni Burtnieki lademe põimjaskihilisel, punakaspruunide vahetriipudega valkjashallil liivakivil. A- ja Bw-horisontidest koosnev $10 \mathrm{~cm}$ tüsedune muld oli arenenud algselt $6,18 \mathrm{~cm}$ tüsedusel liivakivi kihil liivafraktsioonide murenemise ning huumuse, tolmu ja ibe kohapeal kogunemise teel. Lähtematerjali kobestumisel kasvas A-Bw-profiil keskmise kiirusega 0,7$0,8 \mathrm{~mm}$ aastas. Jämedamate fraktsioonide muundumine neis horisontides viis peente osakeste ja keemiliste koostekomponentide kuhjumisele vastavalt 260-290 ning 100-120 $\mathrm{g} \mathrm{m}^{-2}$ aastas. Selle kõrval pole välistatud ka mõningane tolmu ja peenliiva juurdekanne tuule või pindmise külgvoolu teel. Orgaaniline süsinik keskmise aastavooga $25-28 \mathrm{~g} \mathrm{~m}^{-2}$ on kiire ja hoogsa akumulatiivse mullatekke liikumapanevaks jõuks. Fulvohapetele kuulub oluline osa primaarse mullatekke arengus, kusjuures mullatekkes moodustunud Ca-fulvaadid soodustavad akumulatiivsete protsesside järjepidevust. Liivakivist tekkinud mullahorisontide neelamismahutavuse mitmekordne suurenemine on põhjustatud huumuse, tolmu ja ibe kogunemisest mullatekkes.
\end{abstract}

